\title{
Understanding the Antecedents of Organic Food Consumption in Pakistan: Moderating Role of Food Neophobia
}

\author{
Ahsan Akbar ${ }^{1}$, Saqib Ali ${ }^{2, * \mathbb{C}}$, Muhammad Azeem Ahmad ${ }^{3}$, Minhas Akbar ${ }^{2}(\mathbb{D}$ and \\ Muhammad Danish ${ }^{2}$ (D) \\ 1 International Business School, Guangzhou College of South China University of Technology, \\ Guangzhou 510080,China; akbar@gcu.edu.cn \\ 2 Department of Management Sciences, COMSATS University Islamabad (Sahiwal Campus), Sahiwal 57000, \\ Pakistan; minhasakbar@cuisahiwal.edu.pk (M.A.); m.danish33@outlook.com (M.D.) \\ 3 Department of Management Sciences, Barani Institute of Sciences Sahiwal, Sahiwal 57000, Pakistan; \\ azeem@baraniinstitute.edu.pk \\ * Correspondence: saqibali@cuisahiwal.edu.pk
}

Received: 22 September 2019; Accepted: 16 October 2019; Published: 22 October 2019

\begin{abstract}
Environmental and health problems have increased the interest of researchers and practitioners in investigating the factors that affect organic food consumption. However, little attention has been paid to the actual organic food buying behavior, particularly in developing countries like Pakistan. Therefore, the aim of the present study is to determine the actual buying patterns of consumers. For this purpose, a conceptual model based on green perceived value framework which predicts consumer's purchase intention and purchase behavior has been empirically tested. Likewise, moderating role of food neophobia has also been explored. Data is collected from millennials that are under rated but constitute the most important consumer segment in Pakistan. Structural Equation Modeling (SEM) is employed to analyze the data. Results from 221 university students reveal that functional value, social value, emotional value, and conditional value positively influence the consumer purchase intention. Moreover, purchase intention is positively linked to the consumer purchase behavior of organic food. Furthermore, the study findings also confirm the moderating role of food neophobia between purchase intention and consumption of organic food. This paper depicts some noteworthy insights of consumer behavior for organic food producers, marketers, and researchers. At the end, limitations and recommendations for future research are elaborated.
\end{abstract}

Keywords: organic food; food neophobia; Green Perceived Value model

\section{Introduction}

Environmental deterioration and its negative impacts on human health have become a significant concern for academics and organizations nowadays [1]. Industrialization and economic growth have caused over-consumption, which creates many environmental problems (soil, air, water), deterioration of natural resources, depletion of the ozone layer and health hazards [2,3]. These negative impacts on the environment and ecological imbalances make consumers conscious about the consequences of their actions on the environment and human health [4]. In their search for the solution for these adverse effects, consumers are changing their food consumption patterns [5]. Issues like bird flu, mad cow disease, foot, and mouth epidemics, use of pesticides, toxic chemicals, and other biological ingredients to increase per acre yield have created anxiety among consumers about what they eat and its impact on their health and environment [6]. As a result, the consumption of organic foods has seen phenomenal growth in the recent past. 
Organic food is produced through organic agricultural techniques and without the use of conventional methods like ionizing radiation or bioengineering, fertilizers made from sewage sludge or synthetic ingredients [7]. Non-use of chemical pesticides makes it possible for organic products to consume $40 \%$ less energy to produce, and support the welfare of animals, soil and the environment [8]. Organic food consumers consider it a healthier choice, to have better taste, and be fresher than conventional food products [9]. Moreover, as per the latest statistics, Austria, Argentina, China, USA, and Spain hold the top five positions in terms of organic land utilization in 2016 [10]. Due to its perceived benefits, there has been exceptional growth in the sale of organic foods worldwide. The worldwide sales grew from $15 \$$ billion in 1999 to $90 \$$ billion in 2016 with a six-fold growth rate. In this sale, US market has the largest share, surging from 3.4\$ billion in 1999 to $45 \$$ billion in 2017, while the EU stood second, with a sales volume of $33.5 \$$ billion euros in 2016 [8]. Although most of the organic food consumption occurs in developed countries ( $90 \%$ of overall consumption) most organic food is produced in developing countries, especially in South Asian countries [11].

In the Asian region, organic product producers have increased exponentially from 2015 to 2016 and are expected to grow by $370 \%$ in the next 10 years, highest than any region [10]. Pakistan is an economy in South Asia having a $20 \%$ contribution of agriculture to the overall GDP. Pakistan is a country which has a 45299-hectare organic area from a total cultivated area of 22.68 million hectares with 111 commodity producers, but has only a $0.1 \%$ contribution to the global organic industry [10], [12]. Furthermore, despite the benefits of organic foods and their potential, organic food adoption is quiet low in Pakistan [13,14], while Pakistan's households spend half of their income on food products, the highest among 84 countries surveyed by the US Department of Agriculture's Economic Survey. Average Pakistani consumers spent $47.7 \%$ of their income on food, as compared to the US where only $6.6 \%$ of income was spent on food [15]. Consuming unhealthy foods instead of healthy organic food that can prevent non-communicable diseases (NCDs) is a behavioral issue in Pakistan [16] and they do it for the recreational experience, fun and enjoyment [17]. Reports suggest that the overall risk of NCDs is $56 \%$ of the total disease burden in Pakistan. Nevertheless, $60 \%$ of deaths in Pakistan are caused by diabetes, cardiovascular disease, hypertension and a variety of cancers [18]. Moreover, the highest proportion of diet related cardiovascular deaths are recorded in Pakistan [19]. The above mentioned stats suggest that there is a need to identify the factors that can predict consumers' buying behavior of organic food in health-affected countries like Pakistan.

Similarly, identifying factors favoring organic food consumption is also important for marketers to better understand consumers' motives behind their consumption patterns and to design marketing strategies to increase sales [20]. Prior research has identified several key factors associated with intentions to purchase organic food, e.g., health consciousness, price, quality, notations, taste, food safety, and availability [21,22]. Despite some valuable previous studies, there are still three gaps identified by researchers. Firstly, little attention has been paid to millennials in organic food consumption especially no study has considered millennials in Pakistan which are one of the most important segments in organic food consumption. Second, prior studies have not examined actual organic food buying behavior, especially using the Green Perceived Value (GPV) model [23]. Third, Kushwah et al. [24] conducted a review and concluded that very few moderating variables are used in the context of organic food consumption research. Moreover, no prior study has checked moderating role of food neophobia on intention-behavior relationship while it can be the main cause of low organic food adoption in Pakistan.

Millennials are a very crucial segment for marketers because, with all financial constraints, they are motivated to engage in green consumption [25] in any country, especially Asian countries like China, India, and Pakistan which have relatively more young people than others [26]. Pakistan is declared as one of the youngest countries in the world and the second youngest country in South Asian countries after Afghanistan [27]. This makes Pakistan an important segment for green products e.g., organic food. however, it is also found that teenagers are spending the biggest chunk of their 
budget on junk food in Pakistan [16]. Keeping this in mind, this study to understand the factors of organic food consumption is focused on millennials.

Consumer purchasing behavior includes decisions regarding products and services which the consumer intends to buy over time. These intentions differ for different product categories, especially for organic (green) products because consumers who buy organic products have different motives than those who buy conventional products [28]. These motives can be well explained by the GPV model which explains why consumers prefer to buy or not to buy green products and why consumers prefer a specific brand over others. In the green marketing literature and environmental research, GPV is considered an influential factor to determine organic food consumption [23]. GPV is defined as "a consumer's overall appraisal of the net benefits of a product or service between what is received and what is expected based on the consumer's environmental desires, sustainability expectations, and green needs" [29]. GPV helps to understand consumer needs, expectations, and desires from green products during the decision-making process which cannot be explained by a uni-dimensional concept. Due to complex nature of GPV, Sangroya and Kumar [30] developed a multidimensional GPV model which asserts that consumer intention is predicted by four green perceived values, i.e., functional, social, emotional, and epistemic values. These values predict the consumers' intentions to consume the specific green product, in this case, organic products. However, to the best of our knowledge, none of the studies have investigated the consumer perspective regarding organic food by employing the GPV model, particularly in a developing country like Pakistan $[4,11,14,31,32]$. Although the intentions predicted by GPV subsequently lead to the actual buying behavior of a specific product, Woo and Kim [23] contend that it is necessary to check the actual buying behavior of green food by using GPV model.

Furthermore, the previous literature also suggests that intentions are good predictors of behavior but there is often a significant gap between intentions and behavior. One of the underlying reasons for low organic food adoption or this intention-behavior gap could be food neophobia. Food neophobia refers to consumers' refusal or reluctance to try new, unfamiliar and novel foods [33]. For unfamiliar foods like organic food, consumers' intentions and behavior are affected by food neophobia. As Schickenberg et al. [34] claim, consumers with food neophobia are unwilling to try healthy foods. Past researchers have checked the relationship of food neophobia in different food categories [35,36], in different cultural contexts [37] and in different age groups, but the moderating role of food neophobia in organic food consumption has not been examined, particularly in Pakistan where organic products consumption is fairly low. Hence, this study aims to fill this gap by finding the antecedents of consumer intentions by using the GPV model and the moderating effect of food neophobia in consumer intention and consumers' organic food buying behavior in Pakistan.

\section{Literature Review and Hypothesis Development}

\subsection{Millennials and Green Consumption}

The demographic characteristics of consumers are important elements for marketers to design marketing strategies. Age plays an essential role in defining consumer preferences as consumers with similar age brackets usually share common values and consumer behavior. Therefore, taking generation rather than age is a more effective criterion for market segmentation as they undergo the same historical, cultural, political, economic and social events in their life which impact their behavior [38]. Millennials, also referred as generation Y, born between 1982 and 2000, have attracted the attention of marketers, managers, and researchers [39]. Millennials are the most sensitive generation of this era. They care about the environment, health, social values, worry about sustainability and their income $[32,40,41]$. This young segment is innovative, expresses concern about the future, and they are the future of the world [42]. This generation is characterized by the high usage of technology, internet, and social media, seek higher education, display high efforts towards community and social activities, green products, and particularly food safety and sustainability $[40,41,43,44]$. In the USA, 
millennials are progressively involved in organic food consumption. They are more knowledgeable about organic food, willing to pay a premium price and have higher trust in organic labelling [45]. However, south Asian countries have relatively more younger people, and there are only a few studies which consider millennials for organic food consumption [32,46] and specifically none of the studies have considered Pakistan's millennials' organic food consumption. Pakistan has now more young people than it ever had and is considered as one of the youngest countries in world. About $64 \%$ of the population is younger than 30 years and about $29 \%$ of the population lies between the ages of 15 and 29 [27]. Therefore, there is a need to investigate this generational phenomenon to better understand consumers' consumption behavior of organic food in Pakistan.

\subsection{Green Perceived Value Model}

Perceived value refers to consumers' overall evaluation of products' net benefits and utility based on consumers' appraisal [47]. It is basically a subjective construct which is measured by consumers based on different features of the products. It is considered a key determining factor of consumer behavior [48] and has a positive effect on consumers' behavior [49]. The perceived value is considered an important factor both from consumer and industrial perspective and several dimensions (utilitarian and hedonic) of perceived values are also suggested by several researchers [50-55].

In green marketing and environmental research, Chen and Chang [29] suggested a uni-dimensional Green Perceived Value (GPV) model to understand consumers' green purchase intentions. GPV refers to the consumers' overall appraisal of products and services based on green needs, environmental desires, sustainable expectations and the ultimate value received from these products. However, although this uni-dimensional GPV demonstrates well the consumer green intentions but the complexity and multidimensional nature of GPV remains unexplained [23,30,56]. Thereupon, Sangroya and Kumar [30] developed a multidimensional GPV model having four sub constructs (functional value, social value, emotional value, and conditional value). This multidimensional GPV model is based on utilitarian and hedonic benefits and found to be reliable and robust [30]. The four dimensions have a significant effect on consumers intention to buy organic food [23] but the study was limited to purchase intentions. Some researchers have also suggested that there is an intention-behavior gap, so this study also checks the actual buying behavior of organic food as suggested by [23]. Notwithstanding this, due to the low adoption of organic food in Pakistan, the study also examines the moderating role of food neophobia in the intentions-behavior relationship.

\subsection{Functional Value}

Function value refers to the perceived utility obtained from the silent features or utilitarian benefits of a product like functionality, performance, durability, dependability, price, and quality [55]. It is the basic value the consumer desires from any product. In the organic food context, price and quality of the products are very important features. Use of toxic material, animal residues, pesticides, and food additives have increased heath concerns among the consumers [6,57]. Consumers are changing their preferences from conventional foods to organic foods due to health consciousness. Empirically, health concerns are found to be an important factor that influences consumers' decisions regarding organic food [6,58-60]. Testa et al. [61] also confirmed that health consciousness influences consumer attitude to buy organic products.

Price is a very crucial factor because the price of organic foods is higher than conventional foods [59]. However, Padel and Foster [62] argue that consumers are willing to pay a premium whenever they feel the purchase of organic food is justified in terms of its attributes. Still, price is an important feature of organic products because the consumer wants economic value along with quality. Extant research has found a positive influence of functional price value on intentions to buy organic products $[2,6,63]$. Thus, based on previous studies, the following can be hypothesized: 
Hypothesis 1 (H1): Functional value has a significantly positive effect on consumers' intention to buy organic food.

\subsection{Social Value}

Social value is the perceived utility driven through an individual's association with one or more distinctive social groups while choosing a product [55]. It is basically related to social identity and self-image of consumers developed in specific groups like friends, family, and peers. Yoo et al. [64] found that consumers like to engage in green consumption behavior due to reasons beyond its functionality which involve their symbolic identification and value by the society. Moreover, consumers who consume green products motivate others to consume such products for environmental protection [65]. Finch [66] suggested that organic product buyer's behavior differ due to social values. Recent studies found that subjective norms and social values positively influence the consumers' intention to buy organic products $[2,6]$ but few studies could not found any relationship of social value and green consumption behavior $[67,68]$. Hence, it can be hypothesized that:

Hypothesis 2 (H2): Social value has a significant and positive effect on consumers' intention to buy organic food.

\subsection{Emotional Value}

Emotional value is the perceived utility acquired from the association of emotions, feelings and different affective states while choosing between alternative products [55]. These consumer emotions (positive or negative) vary in situations and among individuals which influence consumption behavior. Past experiences regarding product usage predict consumers' future emotions and ultimately purchase intentions [61]. Consumers experience positive emotions like feeling good, satisfied, well-being and comfort while choosing or consuming green products over conventional ones. Recently it is established that these emotional values lead toward organic food consumption [61]. However, these findings are also verified by previous researches on green consumption behavior [68-70] but also have contradictions in green consumption $[3,65,71]$. So, in the organic food domain, it can be hypothesized that:

Hypothesis 3 (H3): Emotional value has a positive and significant effect on consumers' intentions to buy organic food.

\subsection{Conditional Value}

Conditional value refers to "the perceived utility acquired by an alternative as the result of the specific situation or set of circumstances facing the choice maker" [55]. It is basically the perceived value attain by some extrinsic situation that can be economic, environmental and physical circumstances that consumers face at the time of purchase [72]. At the time of purchase, the consumer faces different situations, like time, place, discount, and promotions that affect consumer decision makings and choice behavior [73]. Even same situation at different times can result in different value due to past experience of the consumers [74]. Lin and Huang [68] suggested that different incentives, promotional discounts, and subsidies enable the consumers to involve in pro-environmental behavior. Consumer preferences change whenever situations change. Wen and Noor [69] also argue that cash rebate and government subsidy might drive consumer intentions to use green products. Previous researchers also found positive influence of conditional value on green purchase behavior $[3,68,75]$ while some studies could not find any influence on green consumption $[71,76,77]$. Thus, there is a need for more clarification. Therefore, the following hypothesis is developed:

Hypothesis 4 (H4): Conditional value has a positive and significant effect on consumers' intentions to buy organic food. 


\subsection{Consumer Purchase Intention and Behavior towards Organic Food}

Intentions refer to what extent an individual is willing to perform a certain behavior and tells how many times a person tries to perform a definite behavior [78]. Humans are considered as rational actors, they plan to attain a specific goal and then perform accordingly which means human behavior is shaped by the intentions. Hence, intention to purchase a specific product can result in the adoption of that product or buying behavior of consumers. However, there can be a mismatch between intentions declared by the consumers and what is actual behavior of the consumer at the time of purchase $[79,80]$ which is referred as intention-behavior gap. This intention behavior gap has been identified by different researches on sustainable and green consumption behavior [61,81-83].

This discrepancy of intention-behavior gap is also prevalent in organic food consumption. It is also found that consumers tend to overestimate their organic food consumption and a significant proportion of consumers declare that they buy organic food at least once in a month but in actual fact they didn't buy it at all [61]. Even there is an intention-behavior gap, limited studies exist on actual buying behavior of organic food and prior researches emphasize to ascertain consumers' actual buying behavior $[23,32,84,85]$. As without intention, it is not possible to asses consumer buying behavior of a specific product $[86,87]$. So, based on the above discussion the following hypothesis emerges:

Hypothesis 5 (H5): Purchase intention has a positive and significant effect on consumers' organic food buying behavior.

\subsection{Moderating Effect of Food Neophobia}

Food neophobia is defined as the reluctance, unwillingness or refusal to consume novel foods, unfamiliar foods and is considered to be the important factor to detect human food consumption behavior [33]. This personality trait has a negative relation with food choices whether it be unfamiliar foods, novel foods, or sometimes familiar foods $[88,89]$ which is evidenced by the study results showing that persons with higher food neophobic personality traits are less likely to consume dietary varieties as compared to their less neophobic counterparts [37]. It is also apparent that consumers fear consuming organic food due to a lack of knowledge about healthier processing or advancements in food technologies [90]. In this regard knowledge plays a very important part in reducing the fear of consumers regarding new food innovations [91].

Likewise, consumers are unwilling to adopt healthy foods; such as functional foods in China due to food neophobia which is totally the opposite in Germany [36], whereas, food neophobic personality was not a significant predictor of organic food consumption in Finland [92]. Some studies suggest direct effect of food neophobia on behavior $[36,37,90,93,94]$ others found an indirect effect of food neophobia on consumers intentions $[35,84,89]$.

It is an established fact that organic food consumption is low in Pakistan [13] and there is a gap between intentions and the actual behavior of consumers regarding organic food consumption $[4,14,23]$. Studies also observed that intention-behavior relationship can be strengthened by involving moderating variable [95]. Therefore, food neophobia can play a moderating role in purchase intention and actual buying behavior of organic food in Pakistan. Based on the above arguments, it is hypothesized that:

Hypothesis 6 (H6): Food neophobia moderated the relationship between organic food purchase intentions and actual buying behavior.

\subsection{Theoretical Framework}

Based on the above hypothesis a theoretical framework was developed by taking Green Perceived Value as independent variable, its impact on consumer intention which consequently affects their behavior towards organic food. Food neophobia moderates the relationship of purchase intention and behavior for organic food (Figure 1). 


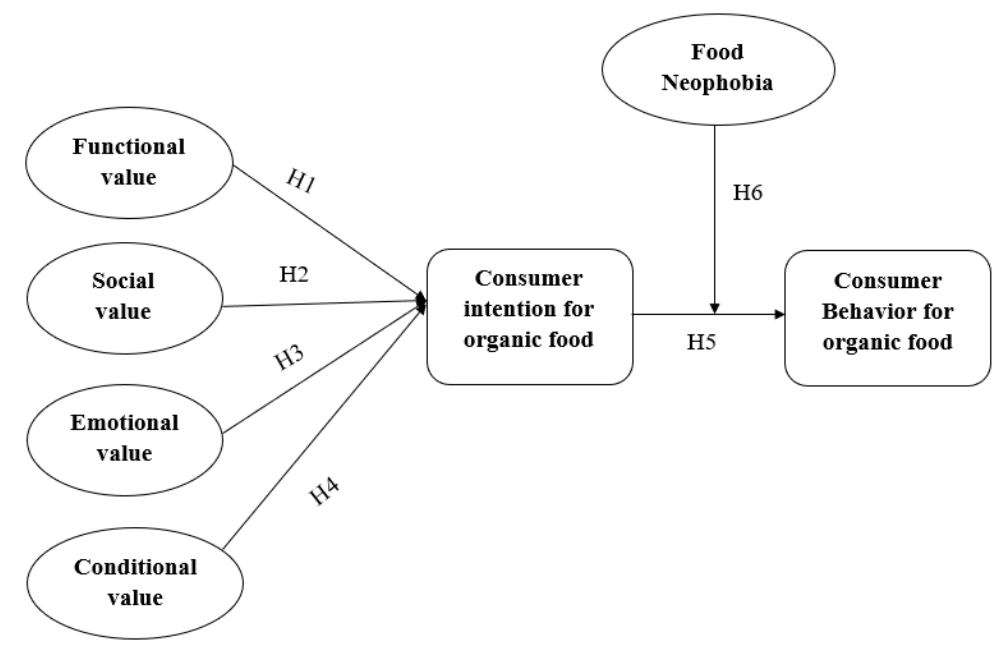

Figure 1. Theoretical Framework.

\section{Materials and Methods}

The study has been conducted in Pakistan to check the actual buying behavior of millennials regarding organic food consumption. For this purpose, a quantitative approach is adopted, and data was collected from university students of two metropolitan cities (Faisalabad and Sahiwal). Blichfeldt and Malene [96] argue that the university students are at a developing stage and they take steps which are suitable to their own lifestyle. Moreover, these young consumers are considered appropriate for this research due to their distinguishing characteristics like care for environment, food sustainability, and green consumption [32]. The data was collected from University of Sahiwal, COMSATS University Islamabad-Sahiwal campus, University of Agriculture Faisalabad and Government College University Faisalabad. It was difficult to reach all departments, so this study encompasses students from management sciences departments of the universities by using non-probability (purposive sampling) technique. Non-probability sampling is appropriate when it is problematic to asses complete sample frame. In this regard, Calder et al. [97] recommend that non-probability sampling is also appropriate for theoretical generalizability. Roscoe et al. [98] suggested that for behavioral studies, sample size between 30 to 500 would be appropriate. To achieve acceptable sample size, 400 questionnaires were distributed as Nulty [99] observed that normal response rate in consumer studies is around $40 \%$ to $60 \%$. A total of 260 questionnaires were returned. After screening, 221 questionnaires were found usable for data analysis, indicating a $55.25 \%$ response rate. The response rate is also in line with the finding of Mellahi and Harris [100] who suggested that the average response rate in subcontinent countries like India and Pakistan is $52.68 \%$.

\section{Measurement Scale}

The questionnaire was distributed in two sections. The first section includes demographic information of the respondents (see Table 1). While second section includes the exogenous and endogenous contracts which were adopted from previous researches (see Appendix A). Seven-point Likert scale ranging from strongly disagree $=1$ to strongly agree $=7$ was used to answer each item of constructs. Four items of functional value were adapted from Biswas and Roy [3]; four items of social value were adapted from Rahnama and Rajabpour [76]; three items of emotional value were adapted from Lin and Huang [68]; four items of conditional value were adapted from Rahnama and Rajabpour [76]; the four items of purchase intention regarding organic food were adapted from Li and Zhong [101]. Only endogenous variable i.e., consumer actual buying behavior was measured by four items that were adapted from Lin and Huang [68]. The five items of moderating variable i.e., food neophobia were adapted from Huang et al. [35]. 
Table 1. Demographic profile.

\begin{tabular}{|c|c|c|c|}
\hline & Characteristics & Frequency & Percentage $\%$ \\
\hline \multirow[t]{2}{*}{ Gender } & Male & 147 & 66.5 \\
\hline & Female & 74 & 33.5 \\
\hline \multirow[t]{4}{*}{ Age } & $18-21$ & 21 & 9.5 \\
\hline & $22-25$ & 53 & 24.0 \\
\hline & $26-29$ & 88 & 39.8 \\
\hline & 30-over & 59 & 26.7 \\
\hline \multirow[t]{4}{*}{ Education } & Intermediate & 40 & 18.0 \\
\hline & Undergraduate & 102 & 46.2 \\
\hline & Graduate & 58 & 26.3 \\
\hline & Professional & 21 & 9.5 \\
\hline \multirow[t]{5}{*}{ Household Income (PKR) } & Less than $50,000(\$ 320)$ & 54 & 24.5 \\
\hline & $50,001(\$ 320)-75,000(\$ 480)$ & 88 & 39.8 \\
\hline & $75,001(\$ 480)-100,000(\$ 638)$ & 39 & 17.6 \\
\hline & $100,001(\$ 638)-125,000(\$ 797)$ & 24 & 10.8 \\
\hline & 125,001 (\$797) and over & 16 & 7.3 \\
\hline
\end{tabular}

\section{Analysis}

Structural Equation Modeling (SEM) is used for data analysis. SEM is an influential multivariate second generation data analysis technique having several benefits over conventional multivariate data analysis techniques in terms of efficiency, convenience, and accuracy [102,103]. SEM is of two types i.e., covariance SEM (CB-SEM) and variance SEM (VB-SEM) [104]. Studies suggest the use of PLS-SEM (VB-SEM) to overcome the data normality issues that normally appears in social sciences studies $[105,106]$. Two stage analysis approach i.e., assessment of measurement and structural model was employed by using Smart PLS $3.0[104,107]$. Validity and reliability is assessed in measurement model and hypotheses are tested in the structural model. Bootstrapping approach (5000 re-sample) is employed to measure the significance of path coefficients [108].

\subsection{Measurement Model}

Assessment of measurement model based on reliability (item reliability and internal consistency reliability) and validity tests (convergent validity and discriminant validity) [109]. Item reliability is measured by outer loading, inter consistency reliability is measured by composite reliability and convergent validity is measured by average variance extracted (AVE). As mentioned in Table 2, all items loading are well above the threshold value of 0.5 [110]. The composite reliability of each construct surpass the cut-off value of 0.7 and AVE exceed the recommended value of 0.5 [111]. The results show that all the AVE values are in between 0.566 (food neophobia) and 0.723 (Consumer intention and consumption behavior for organic food), all CR values are in between 0.820 (Emotional value) and 0.912 (Consumer intention for organic food) and all outer loadings are in between 0.5 and 0.9 (see Table 2 and Figure 2). 
Table 2. Measurement Model Assessment.

\begin{tabular}{|c|c|c|c|c|}
\hline Construct & Item & Loadings & AVE & CR \\
\hline \multirow[t]{4}{*}{ Functional Value } & FV1 & 0.848 & 0.642 & 0.877 \\
\hline & FV2 & 0.857 & & \\
\hline & FV3 & 0.732 & & \\
\hline & FV4 & 0.760 & & \\
\hline \multirow[t]{4}{*}{ Social value } & SV1 & 0.702 & 0.595 & 0.854 \\
\hline & SV2 & 0.790 & & \\
\hline & SV3 & 0.811 & & \\
\hline & SV4 & 0.779 & & \\
\hline \multirow[t]{3}{*}{ Emotional Value } & EMV1 & 0.677 & 0.606 & 0.820 \\
\hline & EMV2 & 0.850 & & \\
\hline & EMV3 & 0.798 & & \\
\hline \multirow[t]{3}{*}{ Conditional value } & CDV1 & 0.852 & 0.722 & 0.886 \\
\hline & CDV2 & 0.869 & & \\
\hline & CDV3 & 0.827 & & \\
\hline \multirow[t]{4}{*}{ Consumer Intention for Organic Food } & CIOF1 & 0.814 & 0.723 & 0.912 \\
\hline & CIOF2 & 0.858 & & \\
\hline & CIOF3 & 0.899 & & \\
\hline & CIOF4 & 0.826 & & \\
\hline \multirow[t]{5}{*}{ Food Neophobia } & FN1 & 0.804 & 0.566 & 0.811 \\
\hline & $\mathrm{FN}$ & 0.657 & & \\
\hline & $\mathrm{FN}$ & 0.693 & & \\
\hline & $\mathrm{FN}$ & 0.560 & & \\
\hline & $\mathrm{FN}$ & 0.675 & & \\
\hline \multirow[t]{4}{*}{ Consumption Behavior for Organic Food } & CBOF1 & 0.729 & 0.723 & 0.830 \\
\hline & CBOF2 & 0.761 & & \\
\hline & CBOF3 & 0.781 & & \\
\hline & CBOF4 & 0.689 & & \\
\hline
\end{tabular}

For discriminant validity, Heterotrait-Monotrait ratio of correlations (HTMT) test was used as it is robust than other methods. According to Kline [112], HTMT value should be less than 0.85 , while Gold et al. [113] argue that this value should be less than 0.90 to confirm discriminant validity. All HTMT values are under the recommended threshold (see Table 3).

Table 3. Discriminant validity (HTMT).

\begin{tabular}{cccccccc}
\hline & CV & CBOF & CIOF & EMV & FN & FV & SV \\
\hline CV & & & & & & & \\
CBOF & 0.197 & & & & & & \\
CIOF & 0.314 & 0.512 & & & & & \\
EMV & 0.133 & 0.597 & 0.771 & & & & \\
FN & 0.204 & 0.573 & 0.738 & 0.792 & & & \\
FV & 0.188 & 0.473 & 0.620 & 0.661 & 0.739 & & \\
SV & 0.067 & 0.352 & 0.394 & 0.457 & 0.466 & 0.479 & \\
\hline
\end{tabular}




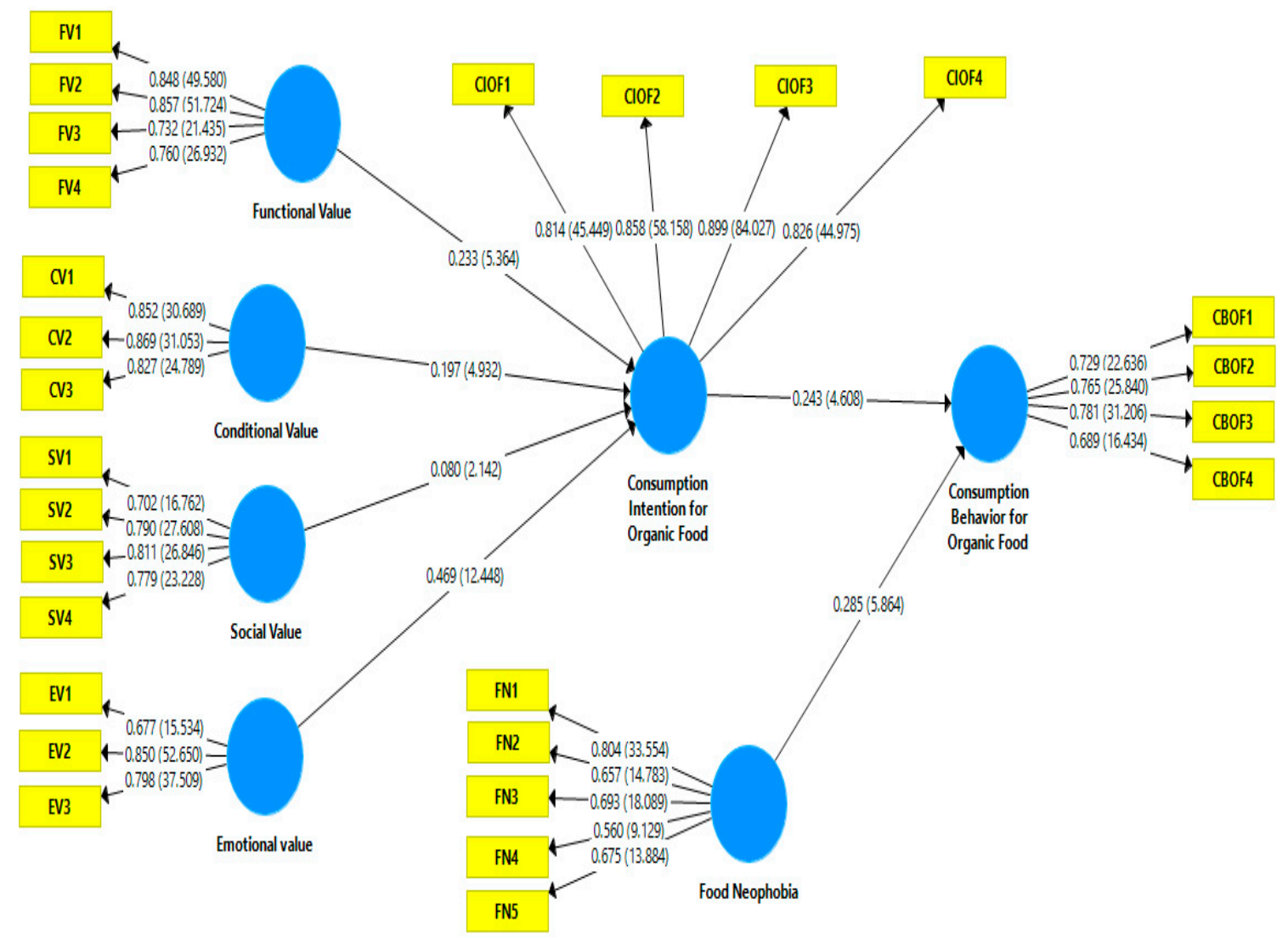

Figure 2. Structural model evaluation (Bootstrap).

\subsection{Structural Model}

After completing the first stage of PLS-SEM i.e., assessment of measurement model, assessment of structural model was performed. Assessment of structural model based on path coefficients ( $\beta$ values), $t$ values, effect size $\left(\mathrm{f}^{2}\right)$, coefficient of determination $\left(\mathrm{R}^{2}\right)$ and predictive relevance $\left(\mathrm{Q}^{2}\right)$. Path coefficients significance was measured by the bootstrapping method (5000 re-sample). The results indicate that all six hypotheses are accepted (see Table 4, Figure 2$)$ i.e., functional value $(\beta=0.233, t=5.364>1.64$, $p<0.05)$, social value $(\beta=0.080, t=2.142>1.64, p<0.05)$, emotional value $(\beta=0.469, t=12.448>1.64$, $p<0.05)$, conditional value $(\beta=0.197, t=4.932>1.64, p<0.05)$ are significant on purchase intentions of organic food. Table 4 shows that purchase intentions have a positive effect on purchase behavior with $(\beta=0.243, t=4.608>1.64, p<0.05)$, and food neophobia moderates the relationship of purchase intention and behavior $(\beta=0.080, t=2.048>1.64, p<0.05) . \mathrm{R}^{2}$ value for purchase intention is 0.493 and for consumption behavior is 0.222 which indicate that model has significant explanatory power for organic food consumption. However, supporting a model only based on $\mathrm{R}^{2}$ is not an effective approach [108]. Therefore, it is better to assess predictive relevance $\mathrm{Q}^{2}$ of the model. It is rule of thumb that if Q2 value is greater than 0 then latent exogenous constructs have high predictive relevance for latent endogenous constructs $[108,114]$. The value of $Q^{2}$ is 0.328 for consumer purchase intention and 0.113 for consumer consumption behavior for organic food It suggests that model has high predictive relevance. $\mathrm{f}^{2}$ value is assessed as per Cohen [115] which indicate that $\mathrm{f}^{2}$ values $0.02,0.15$ and 0.35 are small, medium and large effect respectively. The values of $\mathrm{f}^{2}$ posit that size effect vary from medium to large effect. 
Table 4. Structural Model Results (Hypotheses testing).

\begin{tabular}{cccccccccc}
\hline Hypothesis & Relationship & $\begin{array}{c}\text { Path } \\
\text { Coefficient }\end{array}$ & $\begin{array}{c}\text { Std. } \\
\text { Error }\end{array}$ & $\boldsymbol{t}$ Value & $\boldsymbol{p}$-Value & Supported & $\mathbf{R}^{\mathbf{2}}$ & $\mathbf{Q}^{\mathbf{2}}$ & $\mathbf{f}^{\mathbf{2}}$ \\
\hline H1 & FV -> CIOF & 0.233 & 0.043 & 5.364 & 0.000 & Yes & 0.493 & 0.328 & 0.073 \\
H2 & SV -> CIOF & 0.080 & 0.037 & 2.142 & 0.016 & Yes & & & 0.010 \\
H3 & EMV-> CIOF & 0.469 & 0.038 & 12.448 & 0.000 & Yes & & 0.315 \\
H4 & CDV -> CIOF & 0.197 & 0.040 & 4.932 & 0.000 & Yes & \multirow{2}{*}{0.222} & 0.113 & 0.074 \\
H5 & CIOF -> CBOF & 0.243 & 0.053 & 4.608 & 0.000 & Yes & 0.049 \\
H6 & Moderating effect & 0.080 & 0.036 & 2.042 & 0.000 & Yes & 0.243 & & 0.068 \\
\hline & FN -> CBOF & & & & & & & & \\
\hline
\end{tabular}

\subsection{The Moderating Role of Food Neophobia}

The moderating effect of food neophobia is examined by the interaction effect on the purchase intention and purchase behavior which can be seen in Figure 3. The results demonstrate that food neophobia significantly $(\beta=0.080, t=2.048>1.64, p<0.05)$ moderates the relationship between purchase intention and purchase behavior of organic food. This moderation has changed the coefficient of determination $\mathrm{R}^{2}$ of the model. The $\mathrm{R}^{2}$ value of purchase behavior has increased from 0.222 to 0.243. It means that after the inclusion of food neophobia, the model explains greater variation in the purchase behavior due to exogenous variables. Though, the difference in the variations is not very large yet still its plays a very significant role in analyzing the interaction and moderation effect.

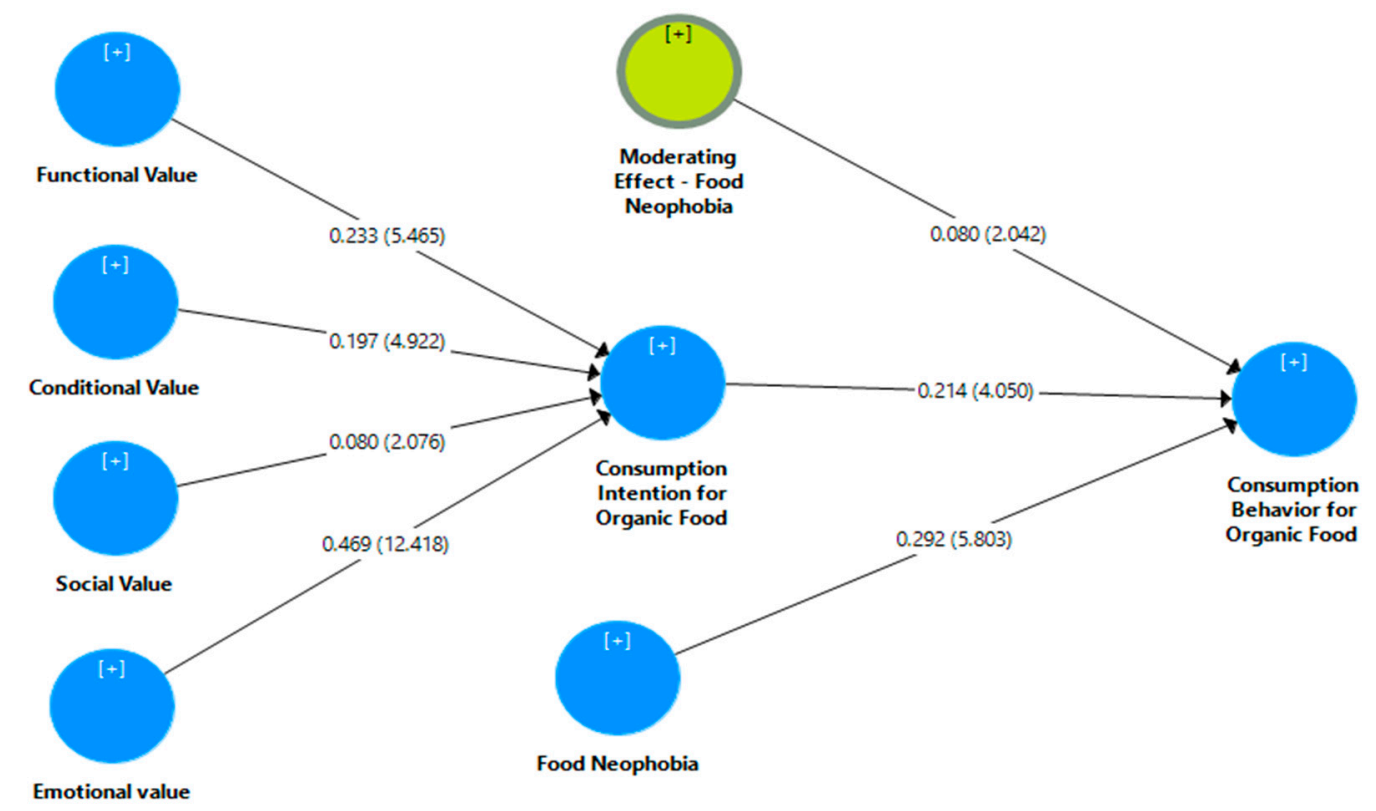

Figure 3. Moderating effect of food neophobia.

\section{Discussion}

Unhealthy eating habits and the negative effects of conventional food (on the soil, environment and animals) have made consumers conscious about their food preferences and they are shifting rapidly towards organic food all over the globe. Despite this worldwide shift of food preferences, organic food adoption is found to be low in Pakistan. Therefore, the primary objective of this study was to identify the factors that affect consumers' actual organic food buying behavior in Pakistan. In line with previous studies $[23,30,56]$, we adopt the GPV model to find consumers' intentions towards organic food and its subsequent effect on the actual buying behavior of organic food. Functional value, social value, emotional value, and conditional value were found to have significant and positive affect on consumer intentions. Moreover, the moderating role of food neophobia is also checked through intention behavior gap. Empirical results show that food neophobia moderates the relationship 
between consumer intentions and consumers buying behavior of organic food in Pakistan. The possible reasons for the results are discussed further.

Functional value is found to be a significant factor to positively affect consumer intentions to buy organic food with the $(\beta=0.233, t=5.364>1.64, p<0.05)$. The functional value is the very basic utility that a consumer desire from a product which in the case of organic food can be its quality, price, health benefits, and taste. The results of this study are in line with the study of Rahnama [6] who found that Iranian women consider functional value while consuming organic food. these results are also verified by the studies conducted in China and Taiwan $[23,116,117]$. The possible reasons for the result can be the price and health factors in Pakistan. The increasing ratio of NCDs is forcing consumers to change their food preferences and consumption patterns. Besides, the price of organic food is higher than conventional food in Pakistan which can be a reason for low adoption. As literature suggests that Pakistani consumers pay more attention towards price than quality to consume organic food [2].

Social values involve the perceived utility attained by the association of alternative capacity of consumers to buy products/services owing to social pressure, status and peer influence. H2 claims that social value has a significant positive effect on consumers' intention to buy organic food which is supported by empirical result with $(\beta=0.080, t=2.142>1.64, p<0.05)$. These result are also in agreement with previous research on green consumerism conducted in Pakistan, India, Bangladesh and Portugal $[2,3,118,119]$. The possible reason for this result can be class consciousness, social status, and self-image of Pakistani consumers among friends, family, and another social group. Consumers in Pakistan especially young consumers care what people think about them, their consumption pattern, and their behavior.

Emotions are a necessary part of humans' life and involve positive feelings like, excitement, joy, feeling of pleasure, enjoyment, doing good and negative feelings like anger, anxiety, fear, worry, and tension. Emotional value is the perceived utility obtained through the positive emotions of individuals derived by green consumption behavior. The results reflect that emotional value positively and significantly influence consumer intentions to buy organic food $(\beta=0.469, t=12.448>1.64, p<0.05)$. The results are in line with recent research of Woo and Kim [23] who found positive effect of emotional value on organic food consumption in china and verified the result of the studies conducted in Taiwan, Iran and USA $[66,68,120]$ and have some contradictions with the results of India, Bangladesh and China $[3,67,118]$. The acceptance of H3 in Pakistan can be due to the fact that Pakistani consumers are emotional decision-maker rather than rational [75].

Conditional value refers to the perceived utility attain by the association of alternative capacity of a different situation. The results reveal that conditional value is positively associated with the consumer intention to consume organic food ( $\beta=0.197, t=4.932>1.64, p<0.05)$. Previous research validate this result $[2,4,6,23,66]$. It means situations like discounts, promotions, incentives, easy availability of organic food can lead consumers towards organic food consumption. The results show that the availability of organic food can be one of the main factors behind the low adoption of organic food.

The study hypothesizes that consumers' intentions positively and significantly affect consumers actual buying behavior of organic food which is accepted by the empirical results with ( $\beta=0.243$, $t=4.608>1.64, p<0.05$ ). These results has validation from some previous researches like Testa et al. found that consumer intention positively affect consumers actual buying behavior of organic food in Italy [61] which is the confirmation of the study conducted in China for green aquatic products consumption [101]. Though results indicate that only 22 percent of the total intended consumers lead toward actual buying behavior. This can be attributed to price and availability of organic food.

Empirical evidence reveals that food neophobia moderates the relationship of purchase intention and behavior of organic food. The results are in agreement with previous studies [35,84]. Food neophobia is reluctant, refusal or fear to use novel or unfamiliar foods. It means that individuals with high food neophobia involve less in organic food buying behavior in Pakistan and vice versa. This is also evident in previous studies which found that consumers avoid healthy eating (functional food) due to food neophobic personality trait $[36,93]$. The probable reasons for this result can be less knowledge 
of organic food. In Pakistan, organic food is at an introductory stage, which makes it unfamiliar to the general consumers. As recent study conducted by Rejmen [121] suggested that consumers are not familiar with sustainability in food choices and there is need of knowledge dissemination.

Based on the above empirical results, marketers should design flexible pricing strategies for organic food in a way that these prices are competitive with traditional food and provide the best value for money as consumers in developing countries search for the best value for money because the majority of the population belong to middle class families and have lower income [2,46]. Moreover, awareness of organic foods' benefits as compare to traditional foods can be initiated to persuade consumers why organic food is more expensive than conventional food. Consumers like to perform those tasks which are encouraged by their social group, peer influence, and co-workers. Word of mouth regarding their behavior matters a lot for them. In this regard, electronic word of mouth campaigns can be launched by producers and food authorities to involve green consumers to motivate others in buying organic food. Positive emotions influence consumers to involve in organic food consumption as they feel good, satisfied, and relaxed, so marketers can also use emotional appeals in advertisements to promote organic food in Pakistan. An integrated message involving quality, price, social affiliation and emotional appeal can be conveyed by the food authorities to make the youth become involved in organic food consumption. In Pakistan, organic foods are only available at big and exclusive superstores [14]. Therefore, the easy availability of organic foods to every consumer could increase the consumption of organic foods. Moreover, promotion strategies, free samples of organic food of organic food products can also affect consumers' intentions to buy organic food. Moreover, food authorities should ensure organic food is available at medium to large stores. In-store awareness programs can be initiated to make consumers involved in green consumption. Thus, food authorities can conduct seminars regarding the benefits of organic foods over conventional foods and should provide samples of these foods, so awareness regarding organic foods' environmental and health benefits can be provided to general consumers as knowledge is very much important to reduce the fear of consumers. Moreover, marketers should use a push strategy at the beginning to maximize the market share of organic products so that consumers become aware of the benefits of organic foods.

\section{Conclusions and Future Research Directions}

The aim of the present study was to identify the factors that affect consumers' actual buying behavior regarding organic foods. For this purpose, a theoretical foundation based on the GPV model was used to observe the actual buying behavior of Pakistani consumers. Moreover, the moderating role of food neophobia was also investigated. Data was collected from university students through valid questionnaires and PLS-SEM was employed to test the hypotheses. Results verify all six hypotheses proposed in this study and suggest that food neophobia is a factor that affects consumers' intention and actual organic food buying behavior.

The SEM results show that functional value, social value, emotional value, and conditional value positively and significantly affect consumers' intentions towards organic food consumption. The results are found to have similarities and disagreements with some previous studies due to differences in culture, context, and product category. In Pakistan, the price and availability of organic food are very crucial factors in organic food consumption. Organic foods are available at high prices and only at exclusive stores in big cities. Hence, setting competitive prices and enhancing availability to a maximum number of consumers can promote consumers' intentions to consume organic food. With this strategy emotional and socially appealing advertisements can be used to motivate consumers as Pakistani consumers are inclined to engage in emotional decisions. Moreover, they consume products that are appreciated by others and increase their social or symbolic value. Furthermore, different incentives like promotions, discounts, and subsidies for organic foods can also increase their purchase intention. Moreover, our study shed light on the relationship between intention and behavior, which is less investigated in the organic food literature suggesting there is need to promote actual buying behavior. It is also observed that consumers' actual buying behavior towards organic food can be 
increased by reducing the food neophobic personality elements of consumers. In this regard, the food authorities of all provinces (Punjab, Sindh, Baluchistan and Khyber Pakhtunkhwa) in Pakistan can play a major role. They can initiate an integrated communication program all around the country to render positive information regarding organic food such as awareness about health and environmental benefits of organic food. Likewise, the causes of NCDs like consumption of unhealthy food should also be emphasized in such campaigns. Moreover, consumers with high food neophobia will purchase organic food if organic food is proven safe and healthy through certification and health labelling by food authorities or government institutions. Therefore, food authorities can make sure that organic food is available at all levels of retail stores to make it accessible for general public.

\section{Limitations and Future Directions}

Although, this study makes several empirical contributions and entails policy implications it still it has some limitations that can be addressed by future researchers. First, this study has considered general organic food consumption in Pakistan. Future studies in this area can examine the consumption of specific organic foods like organic milk, yogurt, cheese, vegetables, and fruits. Second, this research is limited to only Pakistani consumers; future research can undertake a cross-cultural sample for a deep insight into this phenomenon. Third, the study has only investigated the moderating role of one food personality trait i.e., food neophobia but moderating role of other food personality traits i.e., food involvement can be worth an exploration. Fourth, this study focuses only on millennials, future research can explore consumption patterns of a different age groups or demographic category.

Author Contributions: All authors contributed equally to this research. Writing-review \& editing: A.A.; Conceptualization, Formal analysis and Supervision: S.A.; Project Administration: M.A.A.; Writing一review \& editing: M.A.; Writing-original draft and Data curation: M.D.

Funding: This research is funded by the "Excellent PhD Research Program" of the Guangzhou College of South China University of Technology vide grant number: YB180001.

Conflicts of Interest: The authors declare no conflict of interest.

\section{Appendix A}

\section{Appendix A.1. Functional Value}

FV1: Organic foods are good products for the price.

FV2: Organic foods are economical for the attributes they offer.

FV3: Organic foods have an expectable standard quality.

FV4: Organic foods are made from non-hazardous Substances.

\section{Appendix A.2. Social Value}

SV1: Buying organic food would help me to feel acceptable.

SV2: Buying organic food would improve the way that I am perceived.

SV3: Buying organic food would make a good impression on other people.

SV4: Buying organic food would give its owner social approval.

\section{Appendix A.3. Emotional Value}

EV1: Buying organic food instead of conventional food would feel like making a good personal contribution to something better.

EV2: Buying organic food instead of conventional food would feel like the morally right thing.

EV3: Buying organic food instead of conventional food would make me feel like a better person. 
Appendix A.4. Conditional Value

CV1: I would buy organic food instead of conventional food under worsening environmental conditions.

CV2: I would buy organic food instead of conventional food when there is a subsidy for green products.

CV3: I would buy organic food instead of conventional food when there are discount rates for green products or promotional activity.

CV4: I would buy organic food instead of conventional food when green products are available.

\section{Appendix A.5. Purchase Intention for Organic Food}

CIOF1: I would like to buy organic food products to reduce environmental damage.

CIOF2: I would like to buy organic food products to guarantee my health.

CIOF3: As much as possible, I plan to buy organic food products.

CIOF4: I am willing to pay more for organic food products.

Appendix A.6. Consumer Behavior for Organic Food

CBOF1: How often do you buy organic food products?

CBOF2: I always try to buy organic food with green labeling marks.

CBOF3: I buy organic food products even if they have a higher price.

CBOF4: I recommend organic food products that I consume to my relatives and friends.

\section{Appendix A.7. Food Neophobia}

FN1: I do not trust new foods.

FN2: I am constantly sampling new and different foods.

FN3: I am afraid to eat things I have never had before.

FN4: I will eat almost anything.

FN5: If I do not know what is in a food, I won't try it.

\section{References}

1. Yadav, R.; Pathak, G.S. Young consumers' intention towards buying green products in a developing nation: Extending the theory of planned behavior. J. Clean. Prod. 2016, 135, 732-739. [CrossRef]

2. Khan, S.N.; Mohsin, M. The power of emotional value: Exploring the effects of values on green product consumer choice behavior. J. Clean. Prod. 2017, 150, 65-74. [CrossRef]

3. Biswas, A.; Roy, M. Green products: An exploratory study on the consumer behaviour in emerging economies of the East. J. Clean. Prod. 2015, 87, 463-468. [CrossRef]

4. Qasim, H.; Yan, L.; Guo, R.; Saeed, A. The Defining Role of Environmental Self-Identity among Consumption Values and Behavioral Intention to Consume Organic Food. Int. J. Environ. Res. Public Health 2019, 16, 1106. [CrossRef] [PubMed]

5. Tsakiridou, E.; Boutsouki, C.; Zotos, Y.; Mattas, K. Attitudes and behaviour towards organic products: An exploratory study. Int. J. Retail. Distrib. Manag. 2008, 36, 158-175. [CrossRef]

6. Rahnama, H. Effect of Consumption Values on Women Choice Behavior Toward Organic Foods: The Case of Organic Yogurt in Iran. J. Food Prod. Mark. 2017, 23, 144-166. [CrossRef]

7. Van Loo, E.; Caputo, V.; Nayga, R.M.; Meullenet, J.F.; Crandall, P.G.; Ricke, S.C. Effect of organic poultry purchase frequency on consumer attitudes toward organic poultry meat. J. Food Sci. 2010, 75, S384-S397. [CrossRef]

8. Bostan, I.; Onofrei, M.; Vatamanu, A.F.G.; Toderașcu, C.; Lazăr, C.M. An Integrated Approach to Current Trends in Organic Food in the EU. Foods 2019, 8, 144. [CrossRef]

9. Wier, M.; Calverley, C. Market potential for organic foods in Europe. Br. Food J. 2002, 104, 45-62. [CrossRef]

10. FIBL; IFOM-Organics International. The World of Organic Agriculture Statistics \& Emerging Trends 2018; FIBL: Frick, Switzerland; IFOM-Organics International: Bonn, Germany, 2018. 
11. Asif, M.; Xuhui, W.; Nasiri, A.; Ayyub, S. Determinant factors influencing organic food purchase intention and the moderating role of awareness: A comparative analysis. Food Qual. Prefer. 2018, 63, 144-150. [CrossRef]

12. Pakistan Bureau of Statistics. Agriculture Statistics Tables; Pakistan Bureau of Statistics: Islamabad, Pakistan, 2019.

13. Raza, S.A.; Shah, N.; Nisar, W. Consumer Buying Behavior of Organic Food with Respect to Health and Safety Concerns among Adolescents; MPRA Paper 93570; University Library of Munich: Munich, Germany, 2019.

14. Al-Swidi, A.; Huque, S.M.R.; Hafeez, M.H.; Shariff, M.N.M. The role of subjective norms in theory of planned behavior in the context of organic food consumption. Br. Food J. 2014, 116, 1561-1580. [CrossRef]

15. News Desk. Pakistanis spend nearly half of their income on food: Report. Pakistan Today, 3 June 2015. Available online: https://www.pakistantoday.com.pk/2014/08/05/pakistanis-spend-nearly-half-of-theirincome-on-food-report/ (accessed on 13 October 2019).

16. Pakistan Today. Teenagers spend most of their budget on fast food. Pakistan Today, 13 January 2018. Available online: https://www.pakistantoday.com.pk/2018/01/13/teenagers-spend-most-of-their-budget-on-fast-food/ (accessed on 13 October 2019).

17. Yahya, F.; Zafar, R.; Shafiq, S. Trend of Fast Food Consumption and its Effect on Pakistani Society. Food Sci. Qual. Manag. 2013, 11, 1-8.

18. The Express Tribune. Non-communicable diseases: As threat of contagious diseases declines, NCDs rise in Pakistan. The Express Tribune, 15 December 2018. Available online: https:/tribune.com.pk/story/ 1867295/1-non-communicable-diseases-threat-contagious-diseases-declines-ncds-rise-pakistan/ (accessed on 28 August 2019).

19. Afshin, A. Health effects of dietary risks in 195 countries, 1990-2017: A systematic analysis for the Global Burden of Disease Study 2017. Lancet 2019, 393, 1958-1972. [CrossRef]

20. Molinillo, S.; Vidal-branco, M.; Japutra, A. Understanding the drivers of organic foods purchasing of millennials: Evidence from Brazil and Spain. J. Retail. Consum. Serv. 2020, 52, 101926. [CrossRef]

21. Massey, M.; O'Cass, A.; Otahal, P. A meta-analytic study of the factors driving the purchase of organic food. Appetite 2018, 125, 418-427. [CrossRef]

22. Rana, J.; Paul, J. Consumer behavior and purchase intention for organic food: A review and research agenda. J. Retail. Consum. Serv. 2017, 38, 157-165. [CrossRef]

23. Woo, E.; Kim, Y.G. Consumer attitudes and buying behavior for green food products from the aspect of green. Br. Food J. 2019, 121, 320-332. [CrossRef]

24. Kushwah, S.; Dhir, A.; Sagar, M.; Gupta, B. Determinants of organic food consumption. A systematic literature review on motives and barriers. Appetite 2019, 143, 104402. [CrossRef]

25. Jain, S.K.; Kaur, G. Role of Socio-Demographics in Segmenting and Profiling Green Consumers. J. Int. Consum. Mark. 2006, 18, 107-146. [CrossRef]

26. United Nations. Youth population trends and sustainable development. Popul. Facts 2015, 2015, 1.

27. Ahmad, S. Unleashing the potential of a young Pakistan|Human Development Reports. U. N. Devel. Program. 2018. Available online: http://hdr.undp.org/en/content/unleashing-potential-young-pakistan (accessed on 12 September 2019).

28. Wier, M.; Doherty, K.O.; Laura, M.; Millock, K. The character of demand in mature organic food markets: Great Britain and Denmark compared. Food Policy 2008, 33, 406-421. [CrossRef]

29. Chen, Y.; Chang, C.-H. Enhance green purchase intentions The roles of green perceived value, green percived risk, and green trust. Manag. Decis. 2012, 50, 502-520. [CrossRef]

30. Sangroya, D.; Kumar, J. Factors influencing buying behaviour of green energy consumer. J. Clean. Prod. 2017, 151, 393-405. [CrossRef]

31. Yadav, R. Altruistic or egoistic: Which value promotes organic food consumption among young consumers? A study in the context of a developing nation. J. Retail. Consum. Serv. 2016, 33, 92-97. [CrossRef]

32. Yadav, R.; Pathak, G.S. Intention to purchase organic food among young consumers: Evidences from a developing nation. Appetite 2016, 96, 122-128. [CrossRef]

33. Pliner, P.; Hobden, K. Development of a scale to measure the trait of food neophobia in humans. Appetite 1992, 19, 105-120. [CrossRef]

34. Schickenberg, B.; van Assema, P.; Brug, J.; de Vries, N.K. Are the Dutch acquainted with and willing to try healthful food products? The role of food neophobia. Public Health Nutr. 2008, 11, 493-500. [CrossRef] 
35. Huang, L.; Bai, L.; Zhang, X.; Gong, S. Re-understanding the antecedents of functional foods purchase: Mediating effect of purchase attitude and moderating effect of food neophobia. Food Qual. Prefer. 2019, 73, 266-275. [CrossRef]

36. Siegrist, M.; Shi, J.; Giusto, A.; Hartmann, C. Worlds apart. Consumer acceptance of functional foods and beverages in Germany and China. Appetite 2015, 92, 87-93. [CrossRef]

37. Jaeger, S.R.; Rasmussen, M.A.; Prescott, J. Relationships between food neophobia and food intake and preferences: Findings from a sample of New Zealand adults. Appetite 2017, 116, 410-422. [CrossRef]

38. Chaney, D.; Touzani, M.; Slimane, K.B. Marketing to the (new) generations: Summary and perspectives. J. Strateg. Mark. 2017, 25, 179-189. [CrossRef]

39. Brosdahl, D.J.C.; Carpenter, J.M. Shopping orientations of US males: A generational cohort comparison. J. Retail. Consum. Serv. 2011, 18, 548-554. [CrossRef]

40. Valentine, D.B.; Powers, T.L. Generation Y values and lifestyle segments. J. Consum. Mark. 2013, 30, 597-606. [CrossRef]

41. Ivanova, O.; Flores-Zamora, J.; Khelladi, I.; Ivanaj, S. The generational cohort effect in the context of responsible consumption. Manag. Decis. 2019, 57, 1162-1183. [CrossRef]

42. Lee, J.W.; Tai, S. Young consumers' perceptions of multinational firms and their acculturation channels towards western products in transition economies. Int. J. Emerg. Mark. 2006, 1, 212-224. [CrossRef]

43. Deloitte. The Deloitte Global Millennial Survey 2019: Societal Discord and Technological Transformation Create a "Generation Disrupted"; Deloitte: New York, NY, USA, 2019.

44. Lu, L.; Bock, D.; Joseph, M. Green marketing: What the Millennials buy. J. Bus. Strateg. 2013, 34, 3-10. [CrossRef]

45. Organic Trade Association. Millennials and Organic: A Winning Combination; Organic Trade Association: Ottawa, ON, Canada, 2016.

46. Prakash, G.; Singh, P.K.; Yadav, R. Application of consumer style inventory (CSI) to predict young Indian consumer's intention to purchase organic food products. Food Qual. Prefer. 2018, 68, 90-97. [CrossRef]

47. Zeithaml, V.A. Consumer perceptions of price, quality, and value: A means-end model and synthesis of evidence. J. Mark. 1988, 52, 2-22. [CrossRef]

48. Suki, N.M. Green product purchase intention: Impact of green brands, attitude, and knowledge. Br. Food J. 2016, 118, 2893-2910. [CrossRef]

49. Sweeney, J.C.; Soutar, G.N.; Johnson, L.W. The role of perceived risk in the quality-value relationship: A study in a retail environment. J. Retail. 1999, 75, 77-105. [CrossRef]

50. Sweeney, J.C.; Soutar, G.N. Customer perceived value: The development of a multiple item scale. Pergamon 2001, 77, 203-220.

51. Sánchez, J.; Callarisa, L.; Rodríguez, R.M.; Moliner, M.A. Perceived value of the purchase of a tourism product. Tour. Manag. 2006, 27, 394-409. [CrossRef]

52. Tsai, S.P. Utility, cultural symbolism and emotion: A comprehensive model of brand purchase value. Int. J. Res. Mark. 2005, 22, 277-291. [CrossRef]

53. Babin, B.J.; Darden, W.R.; Griffin, M. Utilitarian shopping value. J. Consum. Res. 1994, 20, 644-657. [CrossRef]

54. Walsh, G.; Shiu, E.; Hassan, L.M. Replicating, validating, and reducing the length of the consumer perceived value scale. J. Bus. Res. 2014, 67, 260-267. [CrossRef]

55. Sheth, J.N.; Newman, B.I.; Gross, B.L. Why We Buy What We Buy: A Theory of Consumption Values. J. Bus. Ethics 1991, 22, 159-170. [CrossRef]

56. Hur, W.; Kim, Y.; Park, K. Assessing the Effects of Perceived Value and Satisfaction on Customer Loyalty: A “Green" Perspective. Corp. Soc. Responsib. Environ. Manag. 2012, 20, 146-156. [CrossRef]

57. Huber, M.; Rembialkowska, E.; Średnicka, D.; Bügel, S.; van de Vijver, L.P.L. Organic food and impact on human health: Assessing the status quo and prospects of research. NJAS Wagening. J. Life Sci. 2011, 58, 103-109. [CrossRef]

58. Denver, S.; Jensen, J.D. Consumer preferences for organically and locally produced apples. Food Qual. Prefer. 2014, 31, 129-134. [CrossRef]

59. Rahnama, H. Effect of Consumers' Attitude on Buying Organic Products in Iran. J. Food Prod. Mark. 2016, 22, 381-397. [CrossRef]

60. $\mathrm{Xu}, \mathrm{L}$.; $\mathrm{Wu}, \mathrm{L}$. Food safety and consumer willingness to pay for certified traceable food in China. J. Sci. Food Agric. 2010, 90, 1368-1373. [CrossRef] [PubMed] 
61. Testa, F.; Sarti, S.; Frey, M. Are green consumers really green? Exploring the factors behind the actual consumption of organic food products. Bus. Strateg. Environ. 2019, 28, 327-338. [CrossRef]

62. Padel, S.; Foster, C. Exploring the gap between attitudes and behaviour: Understanding why consumer buy or do not buy organic Food. Br. Food J. 2005, 107, 606-625. [CrossRef]

63. Sadati, S.A.; Sadati, S.A. Survey Consumer Attitude Toward Barriers of Organic Products (OP) in Iran: A Case Study in Gorgan City Department of Agricultural Extension and Education, College of Agricultural. World Appl. Sci. J. 2010, 8, 1298-1303.

64. Yoo, J.J.; Divita, L.; Kim, H.Y. Environmental awareness on bamboo product purchase intentions: Do consumption values impact green consumption? Int. J. Fash. Des. Technol. Educ. 2013, 6, 27-34. [CrossRef]

65. Suki, N.M.; Suki, N.M. Impact of Consumption Values on Consumer Environmental Concern Regarding Green Products: Comparing Light, Average, and Heavy Users'. Int. J. Econ. Financ. Issues 2015, 5, 82-97.

66. Finch, J.E. The Impact of Personal Consumption Values and Beliefs on Organic Food Purchase Behavior. J. Food Prod. Mark. 2006, 11, 3-20. [CrossRef]

67. Wang, H.; Han, X.; Kuang, D.; Hu, Z. The influence factors on young consumers' green purchase behavior: Perspective based on theory of consumption value. In Proceedings of the 2018 Portland International Conference on Management of Engineering and Technology (PICMET), Honolulu, HI, USA, 19-23 August 2018; pp. 1-5.

68. Lin, P.C.; Huang, Y.H. The influence factors on choice behavior regarding green products based on the theory of consumption values. J. Clean. Prod. 2012, 22, 11-18. [CrossRef]

69. Wen, T.; Noor, N.A.M. What affects Malaysian consumers' intention to purchase hybrid car? Asian Soc. Sci. 2015, 11, 52-63.

70. Kanchanapibul, M.; Lacka, E.; Wang, X.; Chan, H.K. An empirical investigation of green purchase behaviour among the young generation. J. Clean. Prod. 2014, 66, 528-536. [CrossRef]

71. Suki, N.M.; Suki, N.M. Consumption values and consumer environmental concern regarding green products. Int. J. Sustain. Dev. World Ecol. 2015, 22, 269-278. [CrossRef]

72. Sánchez-Fernández, R.; Iniesta-Bonillo, M.Á. The concept of perceived value: A systematic review of the research. Mark. Theory 2007, 7, 427-451. [CrossRef]

73. Belk, R.W. An Exploratory Assessment of Situational Effects in Buyer Behavior. J. Mark. Res. 1974, 11, 156-163. [CrossRef]

74. Denys, V. Consumption Values and Destination Evaluation in Destination Decision Making. J. Spat. Organ. Dyn. 2014, 3, 4-22.

75. Ali, S.; Danish, M.; Khuwaja, F.M.; Sajjad, M.S. The Intention to Adopt Green IT Products in Pakistan: Driven by the Modified Theory of Consumption Values. Environments 2019, 6, 53. [CrossRef]

76. Rahnama, H.; Rajabpour, S. Identifying effective factors on consumers' choice behavior toward green products: The case of Tehran, the capital of Iran. Environ. Sci. Pollut. Res. 2017, 24, 911-925. [CrossRef] [PubMed]

77. Biswas, A.; Roy, M. Leveraging factors for sustained green consumption behavior based on consumption value perceptions: Testing the structural model. J. Clean. Prod. 2015, 95, 332-340. [CrossRef]

78. Ajzen, I. The Theory of Planned Behavior. Organ. Behav. Hum. Decis. Process. 1991, 25, 107-114. [CrossRef]

79. Auger, P.; Devinney, T.M. Do what consumers say matter? The misalignment of preferences with unconstrained ethical intentions. J. Bus. Ethics 2007, 76, 361-383. [CrossRef]

80. Papadas, K.; Avlonitis, G.J.; Carrigan, M. Green marketing orientation: Conceptualization, scale development and validation. J. Bus. Res. 2017, 80, 236-246. [CrossRef]

81. Testa, F.; Grappio, P.; Gusmerotti, N.M.; Iraldo, F.; Frey, M. Examining green public procurement using content analysis: Existing difficulties for procurers and useful recommendations. Environ. Dev. Sustain. 2016, 18, 197-219. [CrossRef]

82. Feldmann, C.; Hamm, U. Consumers' perceptions and preferences for local food: A review. Food Qual. Prefer. 2015, 40, 152-164. [CrossRef]

83. Moser, A.K. Thinking green, buying green? Drivers of pro-Environmental purchasing behavior. J. Consum. Mark. 2015, 32, 167-175. [CrossRef]

84. Chen, M.F. Consumer attitudes and purchase intentions in relation to organic foods in Taiwan: Moderating effects of food-related personality traits. Food Qual. Prefer. 2007, 18, 1008-1021. [CrossRef] 
85. Yazdanpanah, M.; Forouzani, M. Application of the Theory of Planned Behaviour to predict Iranian students' intention to purchase organic food. J. Clean. Prod. 2015, 107, 342-352. [CrossRef]

86. Moon, M.A.; Mohel, S.H.; Farooq, A. I green, you green, we all green: Testing the extended environmental theory of planned behavior among the university students of Pakistan. Soc. Sci. J. 2019. [CrossRef]

87. Norton, T.A.; Zacher, H.; Ashkanasy, N.M.; Parker, S.L. Bridging the gap between green behavioral intentions and employee green behavior: The role of green psychological climate. J. Organ. Behav. 2017, 38, 996-1015. [CrossRef]

88. Stratton, L.M.; Vella, M.N.; Sheeshka, J.; Duncan, A.M. Food neophobia is related to factors associated with functional food consumption in older adults. Food Qual. Prefer. 2015, 41, 133-140. [CrossRef]

89. Barrena, R.; Sánchez, M. Neophobia, personal consumer values and novel food acceptance. Food Qual. Prefer. 2013, 27, 72-84. [CrossRef]

90. Falguera, V.; Aliguer, N.; Falguera, M. An integrated approach to current trends in food consumption: Moving toward functional and organic products? Food Control. 2012, 26, 274-281. [CrossRef]

91. Boccia, F.; Covino, D.; Sarnacchiaro, P. Genetically modified food versus knowledge and fear: A Noumenic approach for consumer behaviour. Food Res. Int. 2018, 111, 682-688. [CrossRef]

92. Bäckström, A.; Pirttilä-Backman, A.M.; Tuorila, H. Willingness to try new foods as predicted by social representations and attitude and trait scales. Appetite 2004, 43, 75-83. [CrossRef] [PubMed]

93. Siegrist, M.; Hartmann, C.; Keller, C. Antecedents of food neophobia and its association with eating behavior and food choices. Food Qual. Prefer. 2013, 30, 293-298. [CrossRef]

94. Mak, A.H.N.; Lumbers, M.; Eves, A.; Chang, R.C.Y. The effects of food-related personality traits on tourist food consumption motivations. Asia Pac. J. Tour. Res. 2017, 22, 1-20. [CrossRef]

95. Rehman, S.U.; Bhatti, A.; Mohamed, R.; Ayoup, H. The moderating role of trust and commitment between consumer purchase intention and online shopping behavior in the context of Pakistan. J. Glob. Entrep. Res. 2019, 9, 43. [CrossRef]

96. Blichfeldt, B.S.; Malene, M. Lost in Transition? Student food consumption. High. Educ. 2013, 65, $277-289$. [CrossRef]

97. Calder, B.J.; Phillips, L.W.; Tybout, A.M. Designing Research for Application. J. Consum. Res. 1981, 8, 197. [CrossRef]

98. Roscoe, J.T. Fundamental Research Statistics for the Behavioral Sciences; Holt, Rinehart and Winston: New York, NY, USA, 1975.

99. Nulty, D.D. The adequacy of response rates to online and paper surveys: What can be done? Assess. Eval. High. Educ. 2008, 33, 301-314. [CrossRef]

100. Mellahi, K.; Harris, L.C. Response Rates in Business and Management Research: An Overview of Current Practice and Suggestions for Future Direction. Br. J. Manag. 2016, 27, 426-437. [CrossRef]

101. Li, Y.; Zhong, C. Factors driving consumption behavior for green aquatic products: Empirical research from Ningbo, China. Br. Food J. 2017, 119, 1442-1458. [CrossRef]

102. Henseler, J.; Ringle, C.M.; Sarstedt, M. A new criterion for assessing discriminant validity in variance-based structural equation modeling. J. Acad. Mark. Sci. 2015, 43, 115-135. [CrossRef]

103. Richter, N.; Cepeda-Carrion, G.; Roldán, J.; Ringle, C. European management research using Partial Least Squares Structural Equation Modeling (PLS-SEM). Eur. Manag. J. 2016, 34, 589-597. [CrossRef]

104. Ringle, C.M.; Wende, S.; Becker, J.-M. SmartPLS 3; SmartPLS GmbH: Boenningstedt, Germany, 2015.

105. Osborne, J.W. Improving your data transformations: Applying the Box-Cox transformation. Pract. Assess. Res. Eval. 2010, 15, 1-9.

106. Ramayah, T.; Ahmad, N.H.; Halim, H.A.; Zainal, S.R.M.; Lo, M.-C. Discriminant analysis: An illustrated example. Afr. J. Bus. Manag. 2010, 4, 1654-1667.

107. Becker, J.-M.; Klein, K.; Wetzels, M. Hierarchical latent variable models in PLS-SEM: Guidelines for using reflective-formative type models. Long Range Plan. 2012, 45, 359-394. [CrossRef]

108. Hair, J.F., Jr.; Hult, G.T.M.; Ringle, C.; Sarstedt, M. A Primer on Partial Least Squares Structural Equation Modeling (PLS-SEM), 2nd ed.; SAGE Publications: Thousand Oaks, CA, USA, 2016.

109. Hair, J.F.; Ringle, C.M.; Sarstedt, M. PLS-SEM: Indeed a Silver Bullet PLS-SEM: Indeed a Silver Bullet. J. Mark. Theory Pract. 2011, 19, 37-41. [CrossRef]

110. Hair, J.F.; Sarstedt, M.; Hopkins, L.; Kuppelwieser, V.G. Partial least squares structural equation modeling (PLS-SEM) An emerging tool in business research. Eur. Bus. Rev. 2014, 26, 106-121. [CrossRef] 
111. Anderson, J.C.; Gerbing, D.W. Structural Equation Modeling in Practice: A Review and Recommended Two-Step Approach. Psychl. Bull. 1988, 103, 411-423. [CrossRef]

112. Kline, R.B. Principles and Practice of Structural Equation Modeling; Guilford Publications: New York, NY, USA, 2015.

113. Gold, A.H.; Malhotra, A.; Albert, H. Knowledge Management: An Organizational Capabilities Perspective. J. Manag. Inf. Syst. 2001, 18, 185-214. [CrossRef]

114. Chin, W.W. Handbook of Partial Least Squares; Springer: Berlin, Germany, 2010; pp. 655-656.

115. Cohen, J. Statistical Power Analysis for the Behavioral Sciences, 2nd ed.; Erlbaum Associates: Mahwah, NJ, USA, 1988.

116. Tobin, R.; Larkin, T.; Moane, S. The Irish organic food market: Shortfalls, opportunities and the need for research. J. Sci. Food Agric. 2011, 91, 2126-2131. [CrossRef]

117. Huang, C.H.; Lee, C.H. Consumer willingness to pay for organic fresh milk in Taiwan. China Agric. Econ. Rev. 2014, 6, 198-211. [CrossRef]

118. Solaiman, M.; Halim, M.S.A.; Manaf, A.H.A.; Noor, N.A.M.; Noor, I.M.; Rana, S.S. Consumption Values and Green Purchase Behaviour an Empirical Study. Int. Bus. Manag. 2017, 11, 1223-1233.

119. Gonçalves, H.M.; Lourenço, T.F.; Silva, G.M. Green buying behavior and the theory of consumption values: A fuzzy-set approach. J. Bus. Res. 2016, 69, 1484-1491. [CrossRef]

120. Rahnama, H.; Rajabpour, S. Factors for consumer choice of dairy products in Iran. Appetite 2017, 111, 46-55. [CrossRef] [PubMed]

121. Rejman, K.; Kaczorowska, J.; Halicka, E.; Laskowski, W. Do Europeans consider sustainability when making food choices? A survey of Polish city-dwellers. Public Health Nutr. 2019, 22, 1330-1339. [CrossRef] [PubMed]

(C) 2019 by the authors. Licensee MDPI, Basel, Switzerland. This article is an open access article distributed under the terms and conditions of the Creative Commons Attribution (CC BY) license (http://creativecommons.org/licenses/by/4.0/). 